\title{
DAYA SERAP KULIT KACANG TANAH TERAKTIVASI ASAM BASA DALAM MENYERAP ION FOSFAT SECARA BATH DENGAN METODE BATH
}

\author{
Irdhawati Irdhawati ${ }^{1 *}$, Alling Andini ${ }^{1}$, Made Arsa ${ }^{1}$ \\ ${ }^{1}$ Jurusan Kimia, Fakultas Matematika dan Ilmu Pengetahuan Alam \\ Universitas Udayana \\ *email:irdhawati@unud.ac.id
}

\begin{abstract}
Abstrak
Kulit kacang tanah digunakan sebagai adsorben untuk menyerap ion fosfat dalam larutan. Sebelum digunakan sebagai adsorben, kulit kacang tanah dicuci, dikeringkan, dihaluskan menggunakan blender dan diayak dengan ukuran partikel $\leqq 100$ mesh. Serbuk halus diaktifkan dengan asam $\left(\mathrm{H}_{2} \mathrm{SO}_{4}\right)$ dan basa $(\mathrm{NaOH})$ pada berbagai konsentrasi. Selanjutnya, adsorben dengan dan tanpa aktivasi digunakan untuk menentukan kadar fosfat yang terserap secara optimum. Parameter adsorpsi yang digunakan adalah waktu kontak dan kapasitas adsorpsi. Kapasitas adsorpsi diukur dengan mereaksikan ion fosfat dengan adsorben, dan sisa analit dalam larutan ditambahkan dengan amonium molibdat membentuk senyawa kompleks amonium fosfomolibdat berwarna biru dalam larutan asam. Konsentrasi senyawa kompleks ditentukan dengan metode spektrofotometri UV-Visible.Hasil dalam proses aktivasi menunjukkan konsentrasi optimum asam adalah $0,05 \mathrm{M}$, dan basa sebesar 0,5 M. Waktu kontak optimum diperoleh 45 menit untuk adsorben tanpa aktivasi dan aktivasi basa, sedangkan untuk aktivasi asam 30 menit. Kapasitas adsorpsi optimum berturut-turut adalah $8,5 \mathrm{mg} / \mathrm{g} ; 8,8 \mathrm{mg} / \mathrm{g}$, dan 10,4 mg/g menggunakan adsorben tanpa aktivasi, teraktivasi asam dan teraktivasi basa. Adsorben teraktivasi basa memiliki kapasitas adsorpsi tertinggi dibandingkan adsorben tanpa aktivasi dan teraktivasi asam.
\end{abstract}

Kata kunci: kulit kacang tanah, ion fosfat, adsorpsi, amonium fosfomolibdat

\begin{abstract}
Peanut shell was used as adsorbent to adsorb phosphate ion in solution. Before using as adsorbent, the peanut shell was washed, dried, mashed and sifted with particle size $\leq 100$ mesh. The fine powder was activated by acid $\left(\mathrm{H}_{2} \mathrm{SO}_{4}\right)$ and base $(\mathrm{NaOH})$ with various concentrations. Furthermore, the adsorbent with and without activation was used to determine the optimum phosphate concentration that can be adsorbed. The parameters adsorption such as contact time and adsorption capacity, were examined. The adsorption capacity was measured by reacting the phosphate ion with adsorbent, and the rest of analyte in the solution reacted with ammonium molybdate formed ammonium phospho molybdate complex compound whose blue color in acidic solution. The concentration of complex compound can be determined by UV-Visible spectrophotometry method. The results in activation process showed the optimum concentration of acid is $0.05 \mathrm{M}$, and base is $0.5 \mathrm{M}$. The optimum contact time obtained 45 minutes for adsorbent without and base activated, while 30 minutes for acid activated. The optimum adsorption capacity is $8.5 \mathrm{mg} / \mathrm{g}, 8.8 \mathrm{mg} / \mathrm{g}$, and $10.4 \mathrm{mg} / \mathrm{g}$ using adsorbent without, acid, and base activated, respectively. Adsorbent in base activated has the highest adsorption capacity compared with no and acid activated.
\end{abstract}

Keywords: peanut shell, phosphate ion, adsorption, ammonium phospho molybdate 


\section{Pendahuluan}

Ion fosfat banyak ditemukan di sekitar lingkungan masyarakat yang menghasilkan banyak limbah cair dari usaha kecil seperti limbah laundri. Limbah industri rumahan berasal dari hasil pencucian menggunakan detergen, pewangi, dan pelembut pakaian mengandung ion fosfat. Keberadaan fosfat dalam lingkungan juga berasal dari deposit fosfor, aktivitas pertanian, dan pertambangan batuan fosfat. Keberadaan ion fosfat yang berlimpah di lingkungan akan menghambat penguraian pada proses biologis dan dapat terjadi eutrofikasi yang akan membahayakan lingkungan dan makhluk hidup.

Pengurangan fosfat banyak dilakukan dengan cara adsorpsi yakni menggunakan selulosa dalam biomassa. Menurut Keputusan Menteri Pertanian No. 511 Tahun 2006 Tentang Jenis Komoditi Tanaman Binaan Direktorat Jenderal Perkebunan, komposisi kulit kacang tanah terdiri atas 9,5\% air, 3,6\% abu, 8,4\% protein, $63,5 \%$ selulosa, $13,2 \%$ lignin, dan $1,8 \%$ lemak. Kandungan selulosa dalam kulit kacang tanah yang tinggi merupakan biomassa yang memiliki kemampuan adsorpsi yang besar dalam penyerapan terhadap senyawa kationik dan kecil pada senyawa anionik karena permukaan biomassa memiliki situs negative. Selulosa mengandung situs aktif yakni gugus hidroksil yang dapat membentuk serangkaian reaksi kimia dan melakukan pengikatan dengan senyawa kationik maupun anionik (O'Connell et al., 2008). Kelompok-kelompok hidroksil pada selulosa memiliki kemampuan membuat ikatan hidrogen antar rantai yang berfungsi dalam konfigurasi linier rantai selulosa. Selulosa dapat berikatan dengan fosfat membentuk derivatif fosfat yang selektif untuk posisi $\mathrm{OH}$ pada $\mathrm{C}_{6}$ dengan derajat subtitusi sekitar 0,2 (Granstrom, 2009).

Pengurangan kadar fosfat dilakukan dengan berbagai teknik diantaranya pemanfaatan mikroba yang mampu mengakumulasi fosfat (Khusnuryani,
2008) dan teknik adsorpsi (Agnestisia dkk., 2012). Teknik pengurangan fosfat yang banyak dilakukan saat ini adalah teknik adsorpsi karena lebih efektif, preparasi mudah, dan pembiayaan relatif lebih murah dibanding dengan metode lainnya. Adsorpsi fosfat dilakukan dengan berbagai bahan anorganik maupun organik. Adsorben dengan bahan organik sangat berlimpah di alam yang berasal dari berbagai limbah yang kurang dimanfaatkan kembali. Bahan organik dapat berasal dari tumbuhan maupun hewan. Limbah bahan organik yang mampu menyerap ion fosfat adalah biomassa yang mengandung selulosa karena memiliki gugus hidroksil yang berperan penting dalam penyerapan ion. Salah satu bahan organik yang mengandung selulosa adalah kulit kacang tanah.

\section{Metode Penelitian}

Alat dan Bahan

Alat yang digunakan adalah seperangkat alat spektrofotometer UV-Vis Shimadzu 1800, pengaduk magnetik ICE, blender National, ayakan ukuran 100 mesh, kertas saring Macherey-Nagel, oven Leybold, filler, neraca analitik Shimadzu, dan peralatan gelas yang umum digunakan dalam laboratorium kimia.

Bahan yang digunakan adalah $\mathrm{Na}_{3} \mathrm{PO}_{4}$ (Ajax Chemical) sebagai larutan standar fosfat, kulit kacang tanah, natrium hidroksida (Merck), asam sulfat (Mallinckrodt AR), amonium molibdat (Merck), asam askorbat (Merck), es batu, dan air suling.

\section{Prosedur Penelitian}

\section{Pembuatan sampel adsorben}

Sebanyak 2 kg kulit kacang tanah dicuci dengan air mengalir hingga bersih kemudian dikeringkan di bawah sinar matahari sampai benar-benar kering. Kulit kacang tanah yang telah bersih dan kering dihaluskan dengan blender dan diayak dengan ayakan 100 mesh. Serbuk halus dibagi menjadi tiga bagian untuk 
penentuan daya serap fosfat menggunakan adsorben tanpa aktivasi, teraktivasi basa dan asam.

\section{Aktivasi adsorben}

Sebanyak 50 g serbuk kulit kacang tanah dimasukkan ke dalam gelas beker kemudian ditambahkan $500 \mathrm{~mL}$ natrium hidroksida 1,000 M lalu diaduk dengan kecepatan konstan selama 24 jam. Selanjutnya disaring dan dikeringkan dalam oven pada suhu $80^{\circ} \mathrm{C}$. Serbuk halus kering yang menggumpal dihaluskan dengan blender dan diayak kembali. Dengan cara yang sama dilakukan juga pada serbuk kulit kacang tanah dengan larutan natrium hidroksida $0,500 \mathrm{M}$ dan $0,100 \mathrm{M}$ serta larutan asam sulfat 0,001 ; 0,$005 ; 0,010 ; 0,050$ dan $0,100 \mathrm{M}$

\section{Pembuatan kurva kalibrasi}

Sebanyak 25,0 mL larutan standar fosfat dengan konsentrasi 0,$5 ; 1,0 ; 2,0$ dan 4,0 ppm ditambahkan dengan $2,5 \mathrm{~mL}$ larutan amonium molibdat-asam sulfat serta asam askorbat, dipanaskan hingga terbentuk larutan berwarna biru sempurna. Selanjutnya larutan dikocok sampai homogen dan diukur absorbansinya pada panjang gelombang maksimum menggunakan spektrofotometer UV-Vis, kemudian dihitung persamaan garis untuk menentukan konsentrasi fosfat dalam larutan.

\section{Optimasi konsentrasi asam dan basa}

Sebanyak 0,2000 g masing-masing adsorben teraktivasi ditimbang dan dimasukkan ke dalam gelas beker, lalu ditambahkan 25,0 mL larutan fosfat 100 ppm. Larutan fosfat berisi adsorben diaduk dengan kecepatan konstan selama 15 menit. Selanjutnya campuran disaring dan filtrat ditambahkan ammonium molibdat kemudian larutan diukur absorbansinya pada panjang gelombang maksimum.

\section{Penentuan waktu kontak optimum}

Sebanyak 0,2000 g adsorben tanpa aktivasi dan teraktivasi (asam dan basa) ditimbang dan dimasukkan ke dalam gelas beker, lalu ditambahkan 25,0 mL larutan fosfat $100 \mathrm{ppm}$ kemudian dilakukan kontak selama 15, 30, 45, dan 60 menit dengan pengadukan konstan. Selanjutnya campuran disaring dan filtrat ditambahkan ammonium molibdat kemudian diukur absorbansinya pada panjang gelombang maksimum.

\section{Penentuan konsentrasi Optimum}

Sebanyak 0,2000 g adsorben tanpa aktivasi dan teraktivasi ditimbang dan dimasukkan ke dalam gelas beker lalu ditambahkan 25,0 mL larutan fosfat 25, 50, $75,100,125$ dan 150 ppm kemudian dilakukan kontak selama waktu optimum dengan pengadukan konstan. Selanjutnya campuran disaring dan filtrat ditambahkan ammonium molibdat kemudian yang tidak terserap diukur absorbansinya pada panjang gelombang maksimum.

\section{Penentuan kapasitas adsorpsi}

Penentuan kapasitas adsorpsi fosfat yang terserap oleh adsorben ditentukan sesuai persamaan 1 dengan $\mathrm{W}_{\text {ads }}$ adalah Jumlah zat yang teradsorpsi $(\mathrm{mg} / \mathrm{g})$, B adalah berat sampel yang digunakan $(\mathrm{g})$, $\mathrm{C}_{1}$ adalah konsentrasi larutan awal (ppm), $\mathrm{C}_{2}$ adalah konsentrasi larutan fosfat akhir (ppm) dan $\mathrm{V}$ adalah volume larutan fosfat yang digunakan $(\mathrm{mL})$.

$$
W_{a d s}=\frac{\left(C_{1}-C_{2}\right) \times V}{1000 B}
$$

\footnotetext{
Hasil dan Pembahasan

Kurva kalibrasi fosfat

Pengukuran absorbansi fosfat pada panjang gelombang 823,5 $\mathrm{nm}$ diperoleh persamaan $y=0,0524 x+0,0026$ dengan nilai $r$ sama dengan 0,9994 yang menunjukkan absorbansi dan konsentrasi memiliki korelasi antara kenaikan konsentrasi dan respon yang linier (Gambar 1).
} 


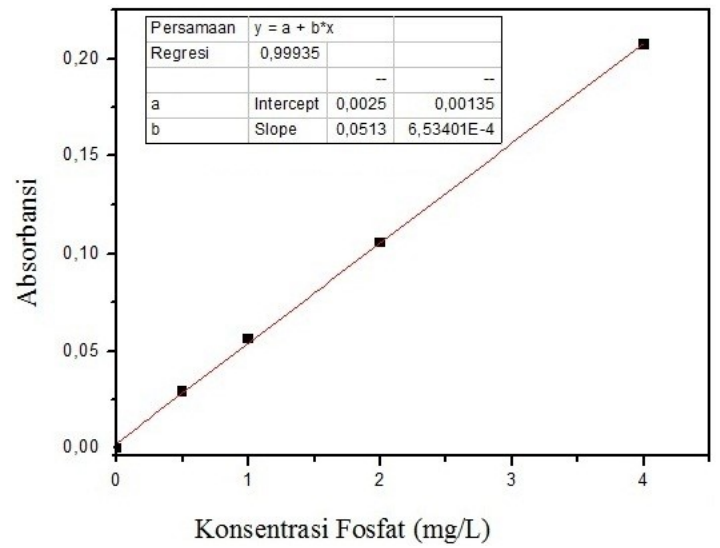

Gambar 1. Kurva Kalibrasi Hubungan antara Konsentrasi dan Absorbansi

\section{Konsentrasi optimum untuk aktivasi}

Aktivasi adsorben menggunakan asam sulfat dengan konsentrasi tinggi $(\geq 0,1 \mathrm{M})$ menyebabkan terjadi reaksi dehidrasi yang mengakibatkan air terlepas dan menyisakan karbon sehingga saat dikeringkan menghasilkan arang (karbon). Aktivasi adsorben dengan natrium hidroksida dapat memisahkan antara selulosa dan lignin dengan reaksi seperti dalam Gambar 2. Pengaruh konsentrasi asam sulfat dalam aktivasi dapat dilihat pada Tabel 1 dan pengaruh konsentrasi natrium hidroksida dalam aktivasi pada Tabel 2.

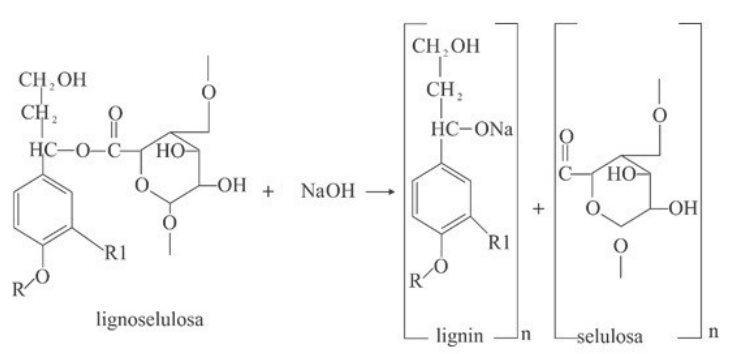

Gambar 2. Reaksi Pemutusan Struktur Lignin dari Selulosa Oleh Natrium Hidroksida.

\section{Waktu kontak optimum}

Penentuan waktu kontak optimum adsorpsi fosfat dilakukan menggunakan adsorben dengan konsentrasi asam sulfat $0,005 \mathrm{M}$, natrium hidroksida $0,5 \mathrm{M}$ dan adsorben tanpa aktivasi dengan larutan fosfat $100 \mathrm{ppm}$ pada waktu kontak 15, 30, 45 dan 60 menit. Perbandingan waktu kontak adsorpsi antara adsorben teraktivasi dan tanpa aktivasi terdapat dalam Tabel 3 dan Gambar 3.

Tabel 1. Pengaruh Konsentrasi Asam Sulfat dalam Aktivasi

\begin{tabular}{cl}
\hline $\begin{array}{c}\text { Konsentrasi } \\
\text { asam sulfat }(\mathrm{M})\end{array}$ & $\mathrm{W}_{\text {ads }}(\mathrm{mg} / \mathrm{g})$ \\
\hline 0,001 & 3,3 \\
0,005 & 7,7 \\
0,010 & 5,6 \\
0,050 & 5,2 \\
0,100 & 3,2 \\
\hline
\end{tabular}

Tabel 2. Pengaruh Konsentrasi Natrium Hidroksida dalam Aktivasi

\begin{tabular}{cl}
\hline $\begin{array}{c}\text { Konsentrasi } \\
\mathrm{NaOH}(\mathrm{M})\end{array}$ & $\mathrm{W}_{\text {ads }}(\mathrm{mg} / \mathrm{g})$ \\
\hline 0,100 & 0,9 \\
0,500 & 2,9 \\
1,000 & 1,8 \\
\hline
\end{tabular}

Tabel 3. Perbandingan Kadar Fosfat yang Terserap dalam Penentuan Waktu Kontak Optimum

\begin{tabular}{cccc}
\hline $\begin{array}{c}\text { Waktu } \\
\text { kontak } \\
(\text { menit })\end{array}$ & $\begin{array}{c}\mathrm{W}_{\text {ads }} \\
\text { tanpa } \\
\text { aktivasi } \\
(\mathrm{mg} / \mathrm{g})\end{array}$ & $\begin{array}{l}\mathrm{W}_{\text {ads }} \\
\text { teraktivasi } \\
\text { asam } \\
(\mathrm{mg} / \mathrm{g})\end{array}$ & $\begin{array}{c}\mathrm{W}_{\text {ads }} \\
\text { teraktivasi } \\
\text { basa }(\mathrm{mg} / \mathrm{g})\end{array}$ \\
\hline 15 & 4,0 & 7,9 & 2,0 \\
30 & 7,5 & 8,5 & 4,6 \\
45 & 8,3 & 7,5 & 9,3 \\
60 & 1,7 & 3,7 & 2,9 \\
\hline
\end{tabular}

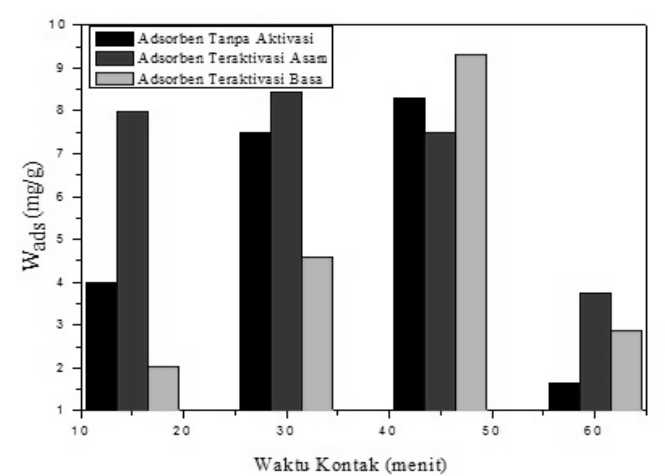

Gambar 3. Perbandingan Kadar Fosfat yang Terserap oleh Adsorben dalam Penentuan Waktu Kontak Optimum

Dari Gambar 3 dapat diketahui waktu kontak optimum adsorben tanpa aktivasi dan teraktivasi natrium hidroksida selama 45 menit, dan adsorben teraktivasi asam 
sulfat 30 menit. Penyerapan ion fosfat semakin besar karena semakin lama waktu kontak maka semakin banyak partikel adsorben yang bereaksi dengan adsorbat sehingga kemampuan adsorpsinya semakin naik. Waktu kontak optimum yang diperoleh merupakan waktu saat terjadi kesetimbangan reaksi antara adsorben dan adsorbat dalam larutan.

\section{Konsentrasi optimum}

Penentuan konsentrasi optimu ditentukan dengan membuat grafik perbandingan antara konsentrasi fosfat yang digunakan dengan banyaknya fosfat tang terserap setiap gramnya ( $\mathrm{W}_{\mathrm{ads}}$ ) pada waktu kontak optimum. Pengaruh konsentrasi optimum dapat dilihat dalam Tabel 4 dan Gambar 2.

Tabel 4. Perbandingan Kadar Fosfat yang Terserap dalam Penentuan Konsentrasi Optimum

\begin{tabular}{cccc}
\hline $\begin{array}{c}\text { Konsentrasi } \\
\text { fonfat awal } \\
(\mathrm{mg} / \mathrm{L})\end{array}$ & $\begin{array}{c}\mathrm{W}_{\text {ads }} \\
\text { tanpa } \\
\text { aktivasi } \\
(\mathrm{mg} / \mathrm{g})\end{array}$ & $\begin{array}{l}\mathrm{W}_{\text {ads }} \\
\text { teraktivasi } \\
\text { asam } \\
(\mathrm{mg} / \mathrm{g})\end{array}$ & $\begin{array}{l}\mathrm{W}_{\text {ads }} \\
\text { teraktivasi } \\
\text { basa } \\
(\mathrm{mg} / \mathrm{g})\end{array}$ \\
\hline 25 & 0,8 & 1,4 & 1,9 \\
50 & 2,7 & 3,7 & 4,9 \\
75 & 5,9 & 6,9 & 5,9 \\
100 & 8,5 & 8,8 & 9,7 \\
125 & 7,6 & 7,1 & 10,4 \\
150 & 6,8 & 6,8 & 8,8 \\
\hline
\end{tabular}

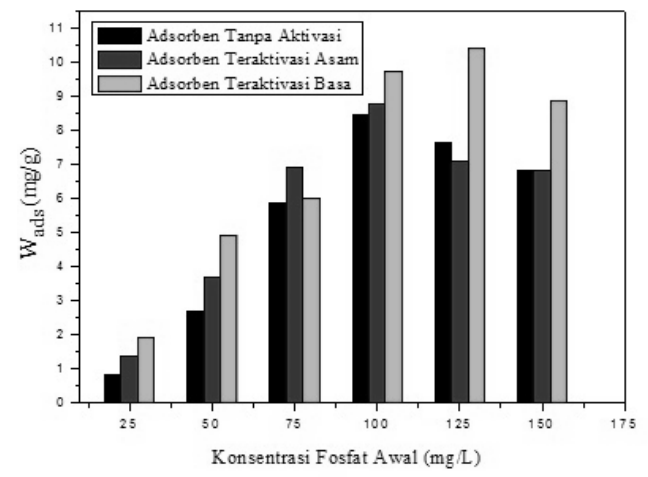

Gambar 4. Perbandingan Kadar Fosfat yang Terserap Oleh Adsorben dalam Penentuan Waktu Kontak Optimum

Dalam Gambar 4 terlihat kadar fosfat yang terserap oleh adsorben tanpa aktivasi $8,5 \mathrm{mg} / \mathrm{g}$ pada konsentrasi $100 \mathrm{ppm}$, kadar fosfat yang terserap oleh adsorben teraktivasi asam $8,8 \mathrm{mg} / \mathrm{g}$ pada konsentrasi 100 ppm dan kadar fosfat yang terserap oleh adsorben teraktivasi basa $10,4 \mathrm{mg} / \mathrm{g}$ pada konsentrasi $125 \mathrm{ppm}$. Daya serap adsorben dalam menyerap ion fosfat meningkat seiring dengan peningkatan konsentrasi ion fosfat dalam larutan namun pada saat melewati konsentrasi optimum terjadi penurunan daya serap adsorben. Hal ini disebabkan semakin tinggi konsentrasi suatu zat terlarut maka yang dapat diadsorpsi oleh adsorben akan semakin tinggi. Akan tetapi jika adsorben telah jenuh maka konsentrasi tidak lagi berpengaruh.

\section{Kesimpulan}

Adsorben kulit kacang tanah teraktivasi basa memiliki kemampuan menyerap ion fosfat lebih baik dibandingkan dengan tanpa aktivasi dan teraktivasi asam. Kulit kacang tanah tanpa aktivasi mampu menyerap fosfat sebesar $8,5 \mathrm{mg} / \mathrm{g}$ dengan waktu kontak optimum 45 menit, kulit kacang tanah teraktivasi asam mampu menyerap $8,8 \mathrm{mg} / \mathrm{g}$ dengan waktu kontak optimum 30 menit, dan kulit kacang tanah teraktivasi basa mampu menyerap 10,4 $\mathrm{mg} / \mathrm{g}$ dengan waktu kontak 45 menit.

\section{Ucapan Terima Kasih}

Penulis mengucapkan terimakasih kepada semua pihak yang telah membantu memberikan saran dan masukan dari pelaksaan penelitian hingga penerbitan tulisan ini.

\section{Daftar Pustaka}

Agnestisia R, Komari N, dan Sunardi, (2012). Adsorpsi Fosfat Menggunakan Selulosa Purun Tikus Termodifikasi Heksadeksil Trimetil Ammonium Bromida (HDTMABr), Jurnal Sains dan Terapan Kimia, 1, $71-86$

Granstrom, M. (2009). Cellulose Derivatives: Synthesis, Properties, and Application, Helsinki University Printing House, Helsinki 
Khusnuryani A. (2008). Mikroba sebagai Agen Penurun Fosfat pada Pengolahan Limbah Cair Rumah Sakit, Proseding Seminar Nasional Aplikasi Sains dan Teknologi 2008, $144-151$

O'Connell, D., Birkinshaw, C. and Francis, T. (2008). Heavy Metal Adsorbents Prepared from The Modification of Cellulose, Bioresource Technology, 9, 6709 6724 